\title{
Knowledge Management for E-service-Delivery - A Conceptual Approach within E-government
}

\author{
Uwe Heck ${ }^{1}$ and Andreas Rogger ${ }^{2}$ \\ ${ }^{1}$ University Fribourg, Department of Informatics, \\ Rue Faucigny 2, CH-1700 Fribourg, Switzerland \\ uwe.heck@unifr.ch \\ ${ }^{2}$ University of Applied Sciences, Lucerne Switzerland (FHZ), \\ Zentralstrasse 9, CH-6002 Lucerne, Switzerland \\ arogger@hsw.fhz.ch
}

\begin{abstract}
The critical challenge for the success of e-government projects is the ability to create new and interesting customer bids. This requires an organization that is able to (re-)design and (re-)invent its business models and processes continuously. Knowledge Management Systems (KMS) can only accommodate such volatile readjustments if their design permits smooth adaptation and (re-) configuration of the underlying business processes. Such a KMS ensures or even improves the required business performance outcomes. We describe here a conceptual approach towards KM, which ensures a very high level of adaptability in order to incorporate dynamic changes in business models and information architecture. The GPWM Project of the public administration of Basel Switzerland - is finally presented as a case study of the proposed approach.
\end{abstract}

\section{Introduction}

Information technology is not the most critical factor in the realization of strategic egovernment projects. More important than IT and its implementation is knowledge of the impact on business and of the implied consequences for the associated business processes. Demands arising from the aims of e-government projects require consistent alignment of all associated resources and processes. Projects that do not take these factors into account lack integration and sustainability and are at best short-term solutions. Information technology projects tend to be of this type.

We frequently find in the public sector a fairly fragmented operational and organizational structure. The responsibilities for delivery of services to the citizen or to business are not transparent enough.

Moving towards a customer-centred administration in the context of e-government brings with it a redistribution of tasks and hence of knowledge. Such a reorganization has a tremendous impact on all the administration's current processes. Knowledge about the processes and the way they interact has to be managed in order to bring about these strategic changes in a controlled manner. In this context, knowledge man- 
agement becomes a critical success factor for the implementation of e-government. Only those organizations that are able to develop a smooth interaction between the organisation's internal knowledge management and e-government, which stretches far beyond the limits of the organisation, will be able to achieve the full potential of egovernment.

Against this background, the canton Basel-Stadt is aiming for a new concept of business process and knowledge management. The intention is to achieve the following mid- and long-term impacts:

- the service performance of the canton Basel-Stadt is to be significantly improved in terms of efficiency, transparency and quality as a result of the transparent and configurable flow of information well as comprehensive responsibilities

- the public reputation of the administration is to be based on well organized and technically functional internal business processes. This is the prerequisite for a more demanding stage in the development of the e-government project, as well as an answer to the concerns related to New Public Management (NPM)

- skills related to workflow and their optimisation are to be promoted in the departments.

\section{Current Situation}

With regard to knowledge management, the concepts and activities are focused on the IT-related use of knowledge, and on a "holistically" oriented design approach, which, for example, integrates human resource management. The first category includes ontology-based knowledge management $[1,2]$ and organizational memory $[3,4]$. The second category includes for example the building block model [5] as well as modelbase knowledge management [6].

As has already been seen in many different areas, it is of only limited use to transpose allegedly proven approaches to knowledge management in private business into the public sector.

One major difficulty is that there is no agreed definition of knowledge management in the private sector (see the case studies in [7]). A variety of projects are labelled as knowledge management, such as for example business process redesign, cultural change or establishment of databases. They often concentrate on instrumental aspects of managing data, information and knowledge. It has so far been impossible to establish a generally accepted strategy in relation to knowledge management. This indicates that knowledge is highly system-dependent. And this is the reason why third party solutions cannot be easily adapted [8].

Moreover, public administration is by nature a highly heterogonous system with a diversity of targets, functions and processes [9]. So far, it has not been possible to develop a knowledge management system for the activities of the public sector without taking into account the uniqueness of the different processes [10]. 
Different authors have argued the necessity to combine knowledge management and e-government $([11,12,13,14,15$ etc. $])$ and thus form the foundations of this work.

\section{Concept}

\subsection{Approach}

This work focuses on an outline showing the technical and conceptual interplay of knowledge management and e-government based on concrete requirements and solutions. The targeted knowledge management of the canton Basel-Stadt is intended to be

- resource-oriented with a focus on intra-corporate knowledge to assure effective and efficient service provision processes

- market and public-oriented to enable the design of new (e-)services, for example in the context of e-government.

Knowledge management and its activities are in this context not considered as a separate task, but as an integral part of the organizational processes of (e-)service delivery and its design, and hence an integral part of business process management.

An e-service can be defined as any asset that is made available via the Internet to drive new value streams or create new efficiencies. To be used, such a service has to be open, serviceable in inter- and intra-organizational business processes and easily composable to varying business processes [16]. Different internal and external resources are needed to make such a (e-)service available and to integrate it in a set of the changing business processes (Fig. 1).

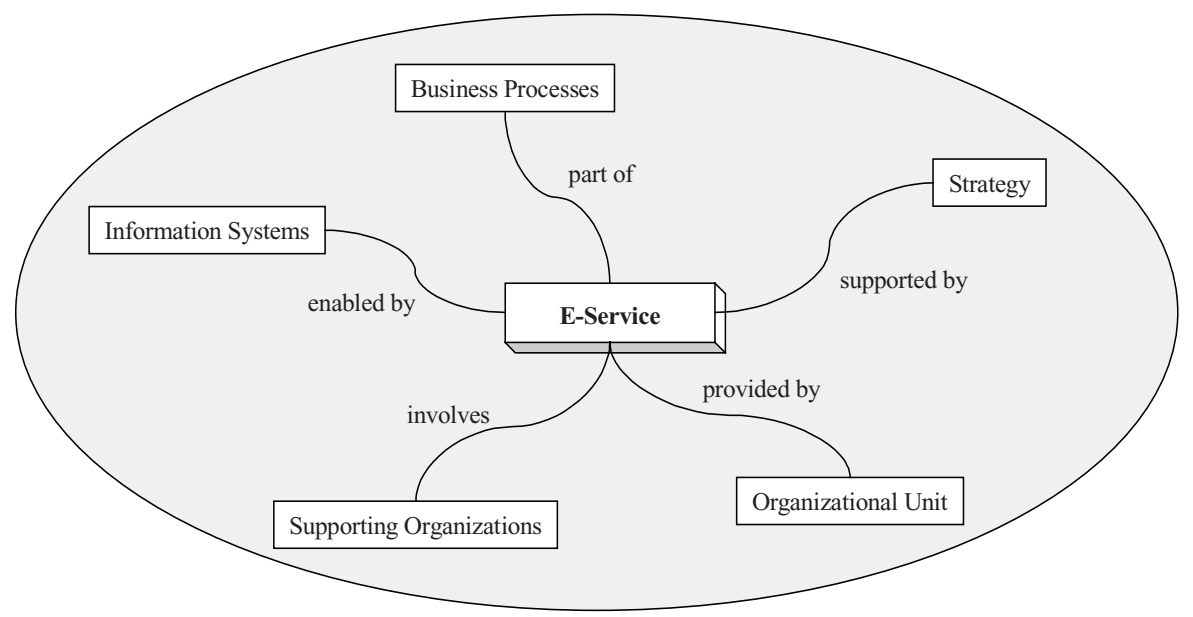

Fig. 1. E-Service resources 


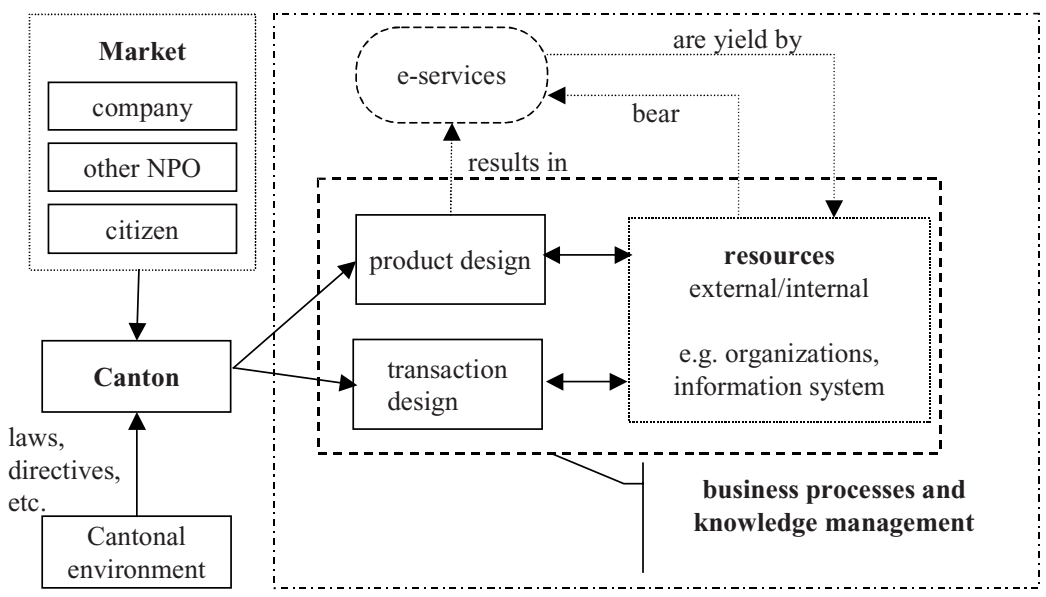

Fig. 2. Business and resource oriented business and knowledge management processes

Different business processes are executed by organizations. Particularly in the case of complex and knowledge-intensive processes and their execution, navigation through these (networked) business processes is done mentally. It is a fundamental task of knowledge management to make these processes requiring knowledge effectively transparent, along with the associated internal and external resources, in order to render them usable by the whole organization e.g. on the basis of the provision of services in the context of e-government (Fig. 2).

\subsection{Steps}

Based on a strategy definition for the project (phase 1: strategic definition), a thorough concept of knowledge management in e-government is worked out (phase 2: conception).

In order to guarantee the targeted implementation of a widespread organizational business process and knowledge management system in the canton Basel-Stadt, pilot schemes (phase 3) have been started. We are deliberately avoiding an integrated, organization wide introduction of business process and knowledge management involving projects of enormous dimensions.

These pilot schemes relate to knowledge-demanding processes which are interdepartmental, interdependent and involve several participants. These projects are of strategic importance for the organization to ensure acceptance and underline the corporate importance of business process and knowledge management. These are projects that have extensive implications for the execution of traditional processes. Based on the experiences of the pilots, the result of the design studies can be validated and extended, and where necessary adjusted. This procedure assures that in a later phase the organization-wide introduction of the business process and knowledge management (phase 4: distribution) is supported by all those involved and that future egovernment activities are supported by these processes. 


\section{Step 1: Strategy definition / requirements and goals}

\begin{tabular}{|c|c|c|}
\hline $\begin{array}{l}\text { (Sub-) goals / con- } \\
\text { tents }\end{array}$ & Results & Key questions \\
\hline $\begin{array}{l}\text { According to the } \\
\text { strategic vision of } \\
\text { the organization - in } \\
\text { our case e- } \\
\text { government - con- } \\
\text { crete requirements } \\
\text { and goals for knowl- } \\
\text { edge management } \\
\text { have to be worked } \\
\text { out and defined. }\end{array}$ & $\begin{array}{l}\text { KM-strategy with detailed } \\
\text { strategic project goals } \\
\text { according to the specific } \\
\text { organization of the canton } \\
\text { Basel-Stadt. } \\
\text { Key figure for how to } \\
\text { deduce and supply KM- } \\
\text { strategy design in public } \\
\text { administrations. }\end{array}$ & $\begin{array}{l}\text { What are the characteristics of a } \\
\text { KM strategy? } \\
\text { What sort of KM-strategy is } \\
\text { suitable for the support of the } \\
\text { introduction of a new business } \\
\text { model in the context of e- } \\
\text { government (e.g. One-Stop- } \\
\text { Shop)? }\end{array}$ \\
\hline
\end{tabular}

\section{Step 2: Design of knowledge management in e-government}

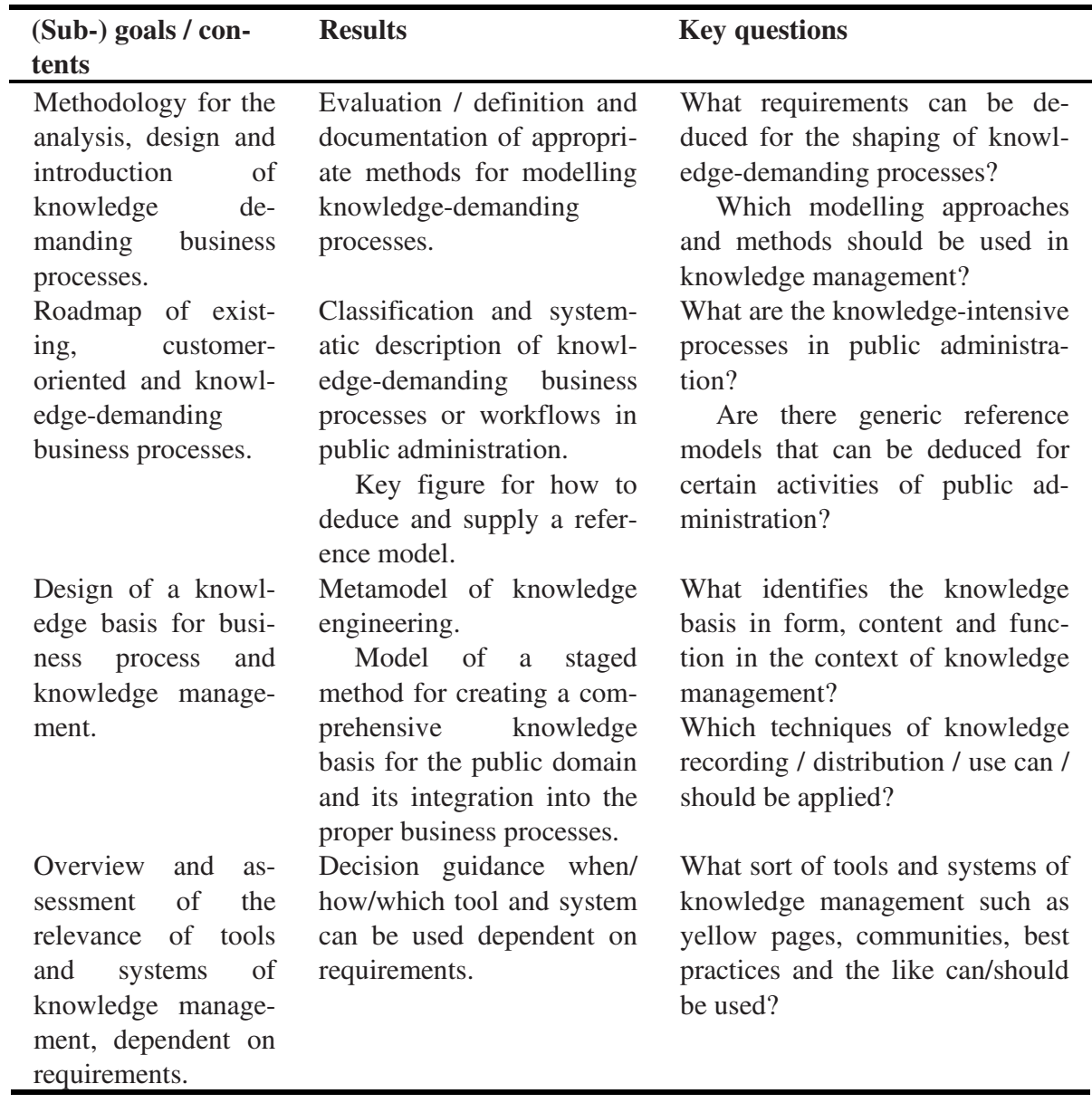




\section{Step 3: Pilot schemes for knowledge management in e-government}

The immigration office of Basel-Stadt is planning a complete reorganization of its customer services, called a "one-stop-shop". Instead of the traditional separation between Swiss and foreign customers, a three-stage model consisting of a front office, an inquiry office and a back office is envisaged. In the medium term, other services of the cantonal administration are also to be integrated. The goal is to create a multifunctional contact point in which the "guichet basel" - a virtual access point as one of various access channels to the administration services - is to be integrated. The clerks in the front and inquiry office will have to supply knowledge-intensive services. Their "mode of operation" will change drastically in a few years. They have to rely upon an informative, effective and user-friendly knowledge base. The connections with business processes and knowledge management are obvious. Business processes and knowledge management have to assist the immigration office in setting up the "one-stop-shop" both from the methodological point of view and by making available appropriate tools.

\begin{tabular}{lll}
\hline $\begin{array}{l}\text { (Sub-) goal / con- } \\
\text { tents }\end{array}$ & Results & Key questions \\
\hline $\begin{array}{l}\text { Field validation of } \\
\text { knowledge man- } \\
\text { agement for e-gov- } \\
\text { ernment. }\end{array}$ & $\begin{array}{l}\text { Methodological support of the } \\
\text { tion of the one-stop-shop. How does the Knowledge } \\
\text { Field report allowing infer- } \\
\text { ences to be made about the con- } \\
\text { cept of knowledge management. } \\
\text { Integration of results/ex- } \\
\text { periences into the concept. } \\
\text { improved with regard to the } \\
\text { experiences? }\end{array}$ \\
\hline
\end{tabular}

\section{Step 4: Distribution of the results}

\begin{tabular}{lll}
\hline $\begin{array}{l}\text { (Sub-) goal / con- } \\
\text { tents }\end{array}$ & Results / milestones & Key questions \\
\hline $\begin{array}{l}\text { Specific concept of } \\
\text { implementation for }\end{array}$ & $\begin{array}{c}\text { Specific concept of implementa- } \\
\text { tion for the canton Basel-Start }\end{array}$ & $\begin{array}{l}\text { Which are the success factors } \\
\text { for an organization-wide im- }\end{array}$ \\
an organization- & Framework for the imple- & plementation of knowledge \\
wide introduction of & mentation of knowledge man- & management? \\
knowledge man- & agement in the public sector. & What are the key compo- \\
agement in the & & nents for a successful frame- \\
canton Basel. & work of knowledge manage- \\
General guid- & ment in the public sector? \\
ance for an imple- & \\
mentation concept & \\
in the public sector. &
\end{tabular}




\section{Conclusion}

In the present paper we pointed out that knowledge management in e-Government is a critical factor for e-Service delivery. An outline has been discussed showing the technical and conceptual interplay of knowledge management and e-government. Therefore a conceptual approach for knowledge management within e-Government has been presented. Further research work is ongoing on the basis of the presented approach. Currently we work on the design and realisation of a knowledge basis according to the proposed business process and knowledge management within eService Delivery.

\section{References}

1. Studer, R. et al.(1999): Informatik-Metohden für das Wissensmanagement. In: Lausen, G.; Schlageter, G. (ed.): Angewandte Informatik und formale Beschreibungsverfahren, Stuttgart, p. 263-274

2. Staab, S., et al. (2001): Knowledge Process and Ontologies. In: IEEE Intelligent Systems, Vol. 16 (1), 2001, Special Issues on Knowledge Management, p. 26-34.

3. Abecker, A. et al. (2001): Business Process-Oriented Delivery of Knowledge Management through Domain Ontologies. In: 2nd Intern. Workshop on Theory and Applications of Knowledge Management, München 2001.

4. Lehner, F. (2000): Organisational Memory. Konzepte und Systeme für das organisatorische Lernen und das Wissensmanagement. München, Wien : Hanser-Verlag.

5. Probst, G. et al. (1999): Wissen managen - wie Unternehmen ihre wertvolle Ressource optimal nutzen, 3. Aufl. Wiesbaden : Gabler-Verlag.

6. Allweyer, T.(1998): Modellbasiertes Wissensmanagement, In: Information Management, Nr. 1 Jg. 1998, p. 37-45.

7. Bornemann, M., Sammer, M. (ed.) (2002): Anwendungsorientiertes Wissensmanagement: Ansätze und Fallstudien aus der betrieblichen und der universitären Praxis. Wiesbaden : Gabler-Verlag.

8. Lenk, K., Traunmüller, R., Wimmer, M. A. (2002): The Significance of Law and Knowledge for Electronic Government. In: Grönlund, A. (ed.) : Electronic Government - Design, Applications and Management, Ideas Group Publishing, p. 61-77.

9. Engel, A. (2001): Prozesswissen als Gegenstand des Wissensmanagements in der öffentlichen Verwaltung. In: Stumme, G. et al. (ed.): Professionelles Wissensmanagement: Erfahrungen und Visionen. Aachen 2001, p.426-434.

10. Menne-Haritz, A. (2001): Das Dienstwissen der öffentlichen Verwaltung. Wissensmanagement für kooperative Entscheidungsprozesse. In: Verwaltung \& Management 7 (2001), p. $198-204$

11. Milner, E. M. 2000: Managing Information and Knowledge in the Public Sector. London : Routledge.

12. Budäus, D. (2000): Vom Neuen Kommunalen Rechnungswesen zum Öffentlichen Management-Informationssystem - Grundlage eines Verwaltungscontrolling. In: Verwaltung \& Management 6(2000) p. 68-76.

13. Wimmer, M.A. 2000: Designing Interactive Systems: Key Issues for a Holistic Approach. Dissertation. Schriften der Johannes-Kepler-Universität Linz 
14. Traunmüller, R., Lenk, K., Wimmer, M. A. (2001): Wissensmanagement und EGovernment. In: Schnurr, H.P. et al. (ed.): Professionelles Wissensmanagement: Erfahrungen und Visionen. Aachen : Shaker Verlag,, p. 381-392

15. KGSt (Hrsg) (2001): Wissensmanagement in Kommunalverwaltungen. Köln: Kommunale Gemeinschaftsstelle für Verwaltungsvereinfachung [KGSt-Bericht 7/2001]

16. Mecella, M. et al. (2001): A Repository of Workflow Components for Cooperative eApplications. SEBD 2001, p. 347-354. 